\title{
JOB SAFETY ANALYSIS IN THE CONTEXT OF THE RISK MANAGEMENT PROCESS
}

doi: $\quad 10.2478 /$ czoto-2019-0005

Date of submission of the article to the Editor: $17 / 11 / 2018$

Date of acceptance of the article by the Editor: $31 / 12 / 2018$

Dorota Wojtyto ${ }^{1}$ - orcid id: 0000-0003-2493-9808

Dariusz Rydz ${ }^{1}$ - orcid id: 0000-0002-9985-8036

Michał Pałęga ${ }^{1}$ - orcid id: 0000-0002-2779-431X

Aleksader S. Arbuz ${ }^{2}$ - orcid id: 0000-0002-2081-0612

${ }^{1}$ Czestochowa University of Technology, Poland, wojtyto.dorota@wip.pcz.pl,

rydz.dariusz@wip.pcz.pl,palega.michal@wip.pcz.pl

${ }^{2}$ Karaganda State Industrial University, Republic of Kazakhstan

Abstract: The article presents the Job Safety Analysis for a Glass Production Line Operator's Workstation in the context of the Risk Management Process. The main tasks performed by the worker have been defined, and then risks associated with each activity and preventive actions have been identified. On this basis, for the Health \& Safety risk analysis and assessment, criteria have been established, which take into account the actual exposure to risks and their probability and results.

Keywords: risk management, job safety, risks

\section{INTRODUCTION}

The Job Safety Analysis consists of three steps: defining the objectives of the tasks performed by the workers, and then establishing a list of activities to be carried out and determining the risks associated with carrying out each of these activities. The analysis accurately fits into the assumptions of the Risk Management System that undertakes the work safety issues in a holistic manner. Above all, it takes into account all work process aspects, such as the context (determinants), the accurate identification of risks for specific tasks, risk analysis and assessment, and the implementation of control mechanisms to improve the employee's work conditions (Marcatto et al., 2016). Taking the above assumptions into considerations, it was assumed, therefore, that the basic purpose of the study would be to put forward a proposal for occupational risk assessment including Job Safety Analysis and the Risk Management Process in accordance with the new ISO 45001:2018 (PN-ISO 45001:2018) Health \& Safety Management System standard, and to indicate the benefits gained from a more accurate and reliable assessment of risks occurring at the workstation. With respect to the presented problem situation it can be noted that the current occupational risk assessment relates largely to the workstation rather than 
specific tasks and activities performed by the worker, which could considerably distort the actual picture of existing risks and general work safety assessment. Moreover, for risk analysis and assessment, available and recommended methods are used, which do not always reflect the existing probability, frequency or definition of the effects in a specific organization and on an actual workstation (Romanowska-Słomka, 2015; Szklarzyk et al., 2016). Therefore, the present article proposes that, in conjunction with the adopted risk assessment method for the tasks, our own assessment criteria, relevant to the work conditions, should be established. To this end, it is furthermore postulated to make and attempt to identify individual Risk Management Process steps for a specific case (establishing the context, identifying the risks, risk analysis, risk assessment, responding to risk, and monitoring and control). Research on the employee work process and occupational risk assessment has carried out in the article for an employee performing job, and then the choice of the adopted risk assessment methodology for the job has been justified. To better understand and achieve its objective, the study has taken the Risk Management Process guidelines resulting from the new ISO 31000:2018 whose framework is compatible with standard ISO 45001:2018 (Risk Management Process steps), while constituting its complement for the entire organization (PN- ISO 31000:2018, PN-ISO 45001:2018).

\section{RESEARCH METHODOLOGY}

To achieve the objective of the study, research on the job risk assessment was undertaken using different research methods, techniques and tools (Wojtyto and Rydz, 2018; Wojtyto, 2018). The research was carried out in November 2018 and concerned an employee performing work activities at the workstations of the Glass Production Line Operator (the first working shift). The number of the employee's working days in the entire month was 20-22. For this purpose, work measurement methods, such as Time Study and the Job Inventory, as well as the survey and the Risk Identification Checklist were used (Martyniak, 1996). The process of work assessment was carried out on the first shift of an eight-hour system, spanned from 5.40 to 14.20 hours, at the Glass Production Line Operator's Workstation operated by a 33-year-old employee in a good health condition, with a three-years' work experience in the company and using all the necessary personal and collective protection equipment, and allowing for breaks for meeting the employee's physiological needs. The research was carried out for a glass production plant active in the Silesian Province and employing 400 workers. The enterprise is part of a foreign corporation and specializes mainly in the production of construction glass.

\section{RESULTS}

As has already been mentioned in the introduction to this article, the Risk Management Process consists of the following stages: establishing the context, identifying the risks, risk analysis, risk assessment, responding to risk, and monitoring and control (Kaczmarek, 2010; PN-ISO 31000:2018, PN-ISO 45001:2018). The identification of risks along with preventive actions and control mechanisms, is shown using a Time Study Record Sheet and the Job Inventory for the Glass Production Line Operator (Table1). 
Table 1

The Time Study Record Sheet and the Job Inventory at the Glass Production Line Operator's Workstation

\begin{tabular}{|c|c|c|c|c|c|c|}
\hline No. & $\begin{array}{c}\text { Durat } \\
\text { ion } \\
\text { [min] }\end{array}$ & $\begin{array}{l}\text { Subject of } \\
\text { observation } \\
\text { (activity) }\end{array}$ & $\begin{array}{l}\text { Po- } \\
\text { siti } \\
\text { on* }\end{array}$ & $\begin{array}{l}\text { Level of } \\
\text { difficulty } \\
\star \star *\end{array}$ & Potential risks & $\begin{array}{l}\text { Preventive actions- } \\
\text { control mechanisms }\end{array}$ \\
\hline 1. & 10 & $\begin{array}{l}\text { Putting on } \\
\text { Personal } \\
\text { Protective } \\
\text { Equipment } \\
\text { and going to } \\
\text { the } \\
\text { workstation }\end{array}$ & $\begin{array}{c}1,2, \\
4,5, \\
6\end{array}$ & 1 & Slip, tripping, fall & $\begin{array}{l}\text { Keeping traffic paths in } \\
\text { appropriate order }\end{array}$ \\
\hline 2. & 25 & $\begin{array}{l}\text { Shift take- } \\
\text { over, } \\
\text { obtaining } \\
\text { information } \\
\text { on glass } \\
\text { production } \\
\text { process } \\
\text { conditions }\end{array}$ & $\begin{array}{l}1,4 \\
5,6\end{array}$ & 2 & $\begin{array}{l}\text { Disinformation, } \\
\text { strain }\end{array}$ & $\begin{array}{l}\text { Detailed reporting on the } \\
\text { whole day and a detailed } \\
\text { communication of } \\
\text { information between } \\
\text { shifts, control by } \\
\text { superiors }\end{array}$ \\
\hline 3. & 45 & $\begin{array}{l}\text { Tin Tank } \\
\text { and Glass } \\
\text { Annealing } \\
\text { Furnace } \\
\text { inspection - } \\
\text { visual, } \\
\text { tactile, } \\
\text { temperature. } \\
\text { Control of } \\
\text { the flow of } \\
\text { process- } \\
\text { aiding gases } \\
\text { (nitrogen, } \\
\text { hydrogen, } \\
\text { sulphur, } \\
\text { oxygen). }\end{array}$ & $\begin{array}{l}1,4 \\
5,6\end{array}$ & 3 & $\begin{array}{l}\text { Burns, hot } \\
\text { microclimate, cuts } \\
\text { and abrasions, } \\
\text { noise, dustiness, } \\
\text { mechanical } \\
\text { hazards (machines } \\
\text { in motion, } \\
\text { radiation, energy } \\
\text { sources: steam, } \\
\text { water, hydraulic } \\
\text { systems, infrared } \\
\text { radiation, contact } \\
\text { with suffocating } \\
\text { gases }\end{array}$ & $\begin{array}{l}\text { Safe work procedure, } \\
\text { Personal Protective } \\
\text { Equipment, i.e. protective } \\
\text { glasses, long-sleeved } \\
\text { incombustible cotton } \\
\text { clothing, leather gloves } \\
\text { and long fire-resistant } \\
\text { aramid gloves, fire- } \\
\text { resistant balaclava } \\
\text { helmet, ear stoppers, gas } \\
\text { leak detectors, training. }\end{array}$ \\
\hline 4. & 20 & $\begin{array}{l}\text { Filling out } \\
\text { Tin Tank } \\
\text { and Glass } \\
\text { Annealing } \\
\text { Furnace } \\
\text { inspection } \\
\text { Control } \\
\text { Cards }\end{array}$ & 1 & 2 & Disinformation & $\begin{array}{l}\text { Detailed communication } \\
\text { of information to the next } \\
\text { shift and the Engineering } \\
\text { Department, and data } \\
\text { archiving. }\end{array}$ \\
\hline
\end{tabular}




\begin{tabular}{|c|c|c|c|c|c|c|}
\hline 5. & 80 & $\begin{array}{l}\text { Glass } \\
\text { production } \\
\text { process } \\
\text { supervision } \\
\text { and } \\
\text { optimization } \\
\text { in the } \\
\text { Control } \\
\text { Room. }\end{array}$ & 1 & 4 & $\begin{array}{l}\text { Production loss, } \\
\text { strain }\end{array}$ & $\begin{array}{l}\text { Properly trained staff, } \\
\text { round-the-clock } \\
\text { Engineering Department } \\
\text { support }\end{array}$ \\
\hline 6. & 60 & $\begin{array}{l}\text { Temperature } \\
\text { inspection of } \\
\text { the Tank } \\
\text { Furnace } \\
\text { bottom using } \\
\text { a laser } \\
\text { pyrometer }\end{array}$ & 5.6 & 3 & $\begin{array}{l}\text { Hot microclimate, } \\
\text { noise, energy } \\
\text { sources: steam, } \\
\text { water, hydraulic } \\
\text { systems }\end{array}$ & $\begin{array}{l}\text { Safe work procedure, } \\
\text { Personal Protective } \\
\text { Equipment, i.e. protective } \\
\text { glasses, long-sleeved } \\
\text { incombustible cotton } \\
\text { clothing, leather gloves } \\
\text { and long fire-resistant } \\
\text { aramid gloves, fire- } \\
\text { resistant balaclava } \\
\text { helmet, ear stoppers, } \\
\text { training. }\end{array}$ \\
\hline 7. & 20 & $\begin{array}{l}\text { Filling out } \\
\text { Tin Tank } \\
\text { and Glass } \\
\text { Annealing } \\
\text { Furnace } \\
\text { inspection } \\
\text { Control } \\
\text { Cards }\end{array}$ & 1 & 2 & Disinformation & $\begin{array}{l}\text { Detailed communication } \\
\text { of information to the next } \\
\text { shift and the Engineering } \\
\text { Department, and data } \\
\text { archiving. }\end{array}$ \\
\hline 8. & 120 & $\begin{array}{l}\text { Fulfilling the } \\
\text { Engineering } \\
\text { Department' } \\
\text { s orders, i.e. } \\
\text { replacing tin } \\
\text { coolers, } \\
\text { tightening } \\
\text { the Tank } \\
\text { Furnace, } \\
\text { cleaning } \\
\text { glass } \\
\text { coolers, } \\
\text { cleaning and } \\
\text { tidying up, } \\
\text { etc. }\end{array}$ & $\begin{array}{l}1,2 \\
3,4, \\
5,6\end{array}$ & 4 & $\begin{array}{l}\text { Burns, hot } \\
\text { microclimate, } \\
\text { noise, cuts and } \\
\text { abrasions, } \\
\text { dustiness, } \\
\text { mechanical } \\
\text { hazards (machines } \\
\text { in motion), } \\
\text { radiation, energy } \\
\text { sources: steam, } \\
\text { water, hydraulic } \\
\text { systems; infrared } \\
\text { radiation; slip, } \\
\text { tripping, fall; } \\
\text { compressed air, } \\
\text { dynamic loads } \\
\text { (manual transport } \\
\text { work), cut, fire, } \\
\text { static loads. }\end{array}$ & $\begin{array}{l}\text { Safe work procedure, } \\
\text { Personal Protective } \\
\text { Equipment, i.e. protective } \\
\text { glasses, long-sleeved } \\
\text { incombustible cotton } \\
\text { clothing, leather gloves } \\
\text { and long fire-resistant } \\
\text { aramid gloves, fire- } \\
\text { resistant balaclava } \\
\text { helmet, dust mask, } \\
\text { training. }\end{array}$ \\
\hline
\end{tabular}




\begin{tabular}{|c|c|c|c|c|c|c|}
\hline 9. & 20 & $\begin{array}{l}\text { Filling out } \\
\text { Tin Tank } \\
\text { and Glass } \\
\text { Annealing } \\
\text { Furnace } \\
\text { inspection } \\
\text { Control } \\
\text { Cards }\end{array}$ & 1 & 2 & Disinformation & $\begin{array}{l}\text { Detailed communication } \\
\text { of information to the next } \\
\text { shift and the Engineering } \\
\text { Department, and data } \\
\text { archiving. }\end{array}$ \\
\hline 10. & 20 & $\begin{array}{l}\text { Control of } \\
\text { cooling } \\
\text { nitrogen flow } \\
\text { over the Tin } \\
\text { Tank }\end{array}$ & $\begin{array}{c}4,5 \\
6\end{array}$ & & $\begin{array}{l}\text { Hot microclimate, } \\
\text { slip, tripping, fall, } \\
\text { contact with } \\
\text { suffocating gases. }\end{array}$ & $\begin{array}{l}\text { Safe work procedure, } \\
\text { Personal Protective } \\
\text { Equipment, i.e. protective } \\
\text { glasses, long-sleeved } \\
\text { incombustible cotton } \\
\text { clothing, leather gloves } \\
\text { and long fire-resistant } \\
\text { aramid gloves, fire- } \\
\text { resistant balaclava } \\
\text { helmet, gas flow and leak } \\
\text { detectors, training. }\end{array}$ \\
\hline 11. & 70 & $\begin{array}{l}\text { Glass } \\
\text { production } \\
\text { process } \\
\text { supervision } \\
\text { and } \\
\text { optimization } \\
\text { in the } \\
\text { Control } \\
\text { Room }\end{array}$ & 1 & 4 & $\begin{array}{l}\text { Production loss, } \\
\text { strain }\end{array}$ & $\begin{array}{l}\text { Properly trained staff, } \\
\text { round-the-clock } \\
\text { Engineering Department } \\
\text { support }\end{array}$ \\
\hline 12. & 10 & $\begin{array}{l}\text { Communicat } \\
\text { ion of } \\
\text { information } \\
\text { of the } \\
\text { process to } \\
\text { the next } \\
\text { shift. }\end{array}$ & $\begin{array}{c}1,4 \\
5\end{array}$ & 2 & $\begin{array}{l}\text { Disinformation, } \\
\text { strain }\end{array}$ & $\begin{array}{l}\text { Detailed reporting on the } \\
\text { whole day, detailed } \\
\text { communication of } \\
\text { information between } \\
\text { shifts, and data archiving. }\end{array}$ \\
\hline 13. & 20 & $\begin{array}{l}\text { Leaving the } \\
\text { Workstation. } \\
\text { Return to the } \\
\text { dressing } \\
\text { room. } \\
\text { Handing } \\
\text { over working } \\
\text { clothing to } \\
\text { the laundry. }\end{array}$ & 6 & 1 & Slip, tripping, fall & $\begin{array}{l}\text { Keeping traffic paths in } \\
\text { appropriate order }\end{array}$ \\
\hline
\end{tabular}

- (1) sitting, (2) kneeling, (3) squatting, (4) standing, (5) bent standing, (6) walking, (7) other nonergonomic (e.g. lying) positions

** 1 -Very easy, 2- easy, 3- average, 4-harder than the other, 5- very difficult)

The table lists 13 activities that are performed during a working shift. Two additional tasks are performed irregularly. The first of them involves cleaning all glass coolers and exit curtains once a month by a team of several persons for a duration of about 4 hours, and the second one is carried out upon an order by the Planning Department 
and may take place as often as up to several times a week (depending on the Production's needs). This is a glass thickness changing activity. The duration of particular activities can be shorter or longer, depending on the process conditions. The saved time is used then for a breakfast break and for meeting physiological needs. The highest level of difficulty occurs in tasks, such as cleaning all glass coolers and exit curtains, exchanging tin coolers, Tank Furnace tightening, cleaning glass coolers, tin melting, glass production process supervision and optimization in the Control Room, as well as glass thickness changing. Body positions most often taken during the working day include a sitting, standing, bent standing and a walking positions; additionally, for work activities with the highest level of difficulty, a kneeling and a squatting positions are also assumed. Activities, such as glass production process supervision and optimization in the Control Room, occur two times during a working shift; a similar is true for filling out Tin Tank and Glass Annealing Furnace inspection Control Cards. Tasks that are distinguished by the occurrence of the largest number of risks are: Tin Tank and Glass Annealing Furnace inspection visual, tactile, temperature; control of the flow of process-aiding gases (nitrogen, hydrogen, sulphur, oxygen); replacement of tin coolers; cleaning the Tank Furnace; cleaning glass coolers; melting tin; cleaning and tidying up all glass coolers and exit curtains; and changing glass thickness.

Summing up the investigation results contained in Table 1, criteria for occupational risk analysis and assessment (Yao, 2018) can thereby be established, taking into account the actual frequency of the occurrence of those risks, exposure to them and their effects, as shown in Table 2. The proposed probability criterion is derived from the number (multiplicity) of repeating risks occurring when particular work activities are performed during a working shift (the number of repeating activities equals to the frequency of occurring risks to those activities, which is subject to summation). Exposure, on the other hand, results from the duration of an employee's exposure to a given risk arising from the performance of that activity (the duration of the performance of an activity equals to the duration of the employee's exposure to a given risk; e.g. 10 minutes of performing an activity $=10$ minutes of exposure to the risk during a working day; so, $10 \mathrm{~min} . / 520 \mathrm{~min}=0.02$ working day). If a risk occurs with several performed activities, then the duration of exposure to that risk is subject to summation, just like the multiplicity of its occurrence (probability).

Table 2

Criteria for occupational risk analysis and assessment at the Glass Production Line Operator's Workstation (probability, effects, exposure)

\begin{tabular}{|l|c|c|l|c|c|}
\hline $\begin{array}{c}\text { Probability } \\
-\mathbf{P}\end{array}$ & Scale & Description & Effects- S & $\begin{array}{c}\text { Scal } \\
\mathbf{e}\end{array}$ & Description \\
\hline Rare & 1 & $\begin{array}{c}\text { Occurs once in } \\
\text { a working shift }\end{array}$ & Negligible & 1 & $\begin{array}{c}\text { Small injuries, sick } \\
\text { absenteeism up to 1 week }\end{array}$ \\
\hline $\begin{array}{l}\text { Little } \\
\text { probable }\end{array}$ & 2 & $\begin{array}{c}\text { Occurs 2 - 4 } \\
\text { times in a } \\
\text { working shift }\end{array}$ & Small & 2 & $\begin{array}{c}\text { Small injuries, sick } \\
\text { absenteeism up to a month }\end{array}$ \\
\hline Medium & 3 & $\begin{array}{c}\text { Occurs 5-6 } \\
\text { times }\end{array}$ & Medium & 3 & $\begin{array}{c}\text { Considerable injuries, sick } \\
\text { absenteeism up to half a } \\
\text { year }\end{array}$ \\
\hline Probable & 4 & $\begin{array}{c}\text { Occurs 7-8 } \\
\text { times in a }\end{array}$ & Serious & 4 & $\begin{array}{c}\text { Serious bodily injury, sick } \\
\text { absenteeism over half a }\end{array}$ \\
\hline
\end{tabular}




\begin{tabular}{|l|c|c|l|c|c|}
\hline & & working shift & & year \\
\hline $\begin{array}{l}\text { Almost } \\
\text { certain }\end{array}$ & 5 & $\begin{array}{l}\text { Occurs more } \\
\text { than 8 times in } \\
\text { a working shift }\end{array}$ & $\begin{array}{l}\text { Very } \\
\text { serious }\end{array}$ & 5 & Death \\
\hline Exposure- E & Scale & \multicolumn{2}{|c|}{ Description } \\
\hline Very frequent & 1 & \multicolumn{2}{|c|}{ Above 0.75 (above 390 minutes) } \\
\hline Frequent & 2 & $0.75>\mathrm{E}<0.5$ working day (between 260 and 390 minutes) \\
\hline Occasional & 3 & $0.5>\mathrm{E}<0.2$ working day (between 260 and 104 minutes) \\
\hline Minimal & 4 & $0.2>\mathrm{E}<0.06$ working day (between 104 and 31 minutes) \\
\hline Negligible & 5 & E $<0.06$ working day (less than 31 minutes) \\
\hline
\end{tabular}

To calculate the value of occupational risk at the Glass Production Line Operator's Workstation, the values of exposure, probability and effects need to be multiplied by themselves $(R=P x E x S)$. The results of this calculation, together with substantiation, are presented in Table 3.

Table 3

The results of risk calculation, together with substantiation

\begin{tabular}{|c|c|c|c|c|c|c|c|}
\hline No & Risk & Substantiation & $\mathbf{P}$ & $\mathbf{E}$ & $\mathbf{S}$ & $\mathbf{R}$ & Risk level \\
\hline 1. & $\begin{array}{l}\text { Slip, } \\
\text { tripping, fall }\end{array}$ & $\begin{array}{l}\text { Occurs } 4 \text { times in a working shift; } \\
\text { exposure to these risks is } 170 \text { minutes; } \\
\text { possible minor injuries, sick } \\
\text { absenteeism up to one month }\end{array}$ & 2 & 3 & 2 & 12 & acceptable \\
\hline 2. & $\begin{array}{l}\text { Cut by } \\
\text { sharp } \\
\text { protruding } \\
\text { parts }\end{array}$ & $\begin{array}{l}\text { Occurs } 2 \text { times in a working shift; } \\
\text { exposure to the risks is } 165 \text { minutes. } \\
\text { Minor injuries, sick absenteeism up to } \\
\text { one month }\end{array}$ & 2 & 3 & 2 & 12 & acceptable \\
\hline \multirow[t]{2}{*}{3.} & Burns & $\begin{array}{l}\text { Occurs } 2 \text { times in a working shift; } \\
\text { exposure to these risks is } 165 \text { minutes. } \\
\text { Considerable injuries, sick absenteeism } \\
\text { up to half a year }\end{array}$ & 2 & 3 & 3 & 12 & acceptable \\
\hline & $\begin{array}{l}\text { Hot } \\
\text { microclimat } \\
\text { e }\end{array}$ & $\begin{array}{l}\text { Occurs } 4 \text { times in a working shift; } \\
\text { exposure to these risks is } 245 \text { minutes; } \\
\text { possible minor injuries, sick } \\
\text { absenteeism up to one month }\end{array}$ & 2 & 3 & 2 & 12 & acceptable \\
\hline 4. & Dustiness & $\begin{array}{l}\text { Occurs } 2 \text { times in a working shift; } \\
\text { exposure to these risks is } 165 \text { minutes; } \\
\text { possible minor injuries, sick } \\
\text { absenteeism up to one month }\end{array}$ & 2 & 3 & 2 & 12 & acceptable \\
\hline 5. & Noise & $\begin{array}{l}\text { Occurs } 3 \text { times in a working shift; } \\
\text { exposure to these risks is } 225 \text { minutes; } \\
\text { possible minor injuries, sick } \\
\text { absenteeism up to one month }\end{array}$ & 2 & 3 & 2 & 12 & acceptable \\
\hline 6. & $\begin{array}{l}\text { Infrared } \\
\text { radiation }\end{array}$ & $\begin{array}{l}\text { Occurs } 2 \text { times in a working shift; } \\
\text { exposure to these risks is } 165 \text { minutes; } \\
\text { minor injuries, sick absenteeism up to } 1 \\
\text { week }\end{array}$ & 2 & 3 & 1 & 6 & acceptable \\
\hline 7. & $\begin{array}{l}\text { Contact } \\
\text { with } \\
\text { suffocating }\end{array}$ & $\begin{array}{l}\text { Occurs once in a working shift; exposure } \\
\text { to these risks is } 45 \text { minutes; serious } \\
\text { bodily injury, sick absenteeism above }\end{array}$ & 2 & 2 & 4 & 16 & acceptable \\
\hline
\end{tabular}




\begin{tabular}{|c|c|c|c|c|c|c|c|}
\hline & gases & half a year & & & & & \\
\hline 8. & $\begin{array}{l}\text { Dynamic } \\
\text { loads }\end{array}$ & $\begin{array}{l}\text { Occurs once in a working shift; exposure } \\
\text { to these risks is } 120 \text { minutes; possible } \\
\text { minor injuries, sick absenteeism up to } \\
\text { one month }\end{array}$ & 2 & 3 & 2 & 12 & acceptable \\
\hline 9. & Static loads & $\begin{array}{l}\text { Occurs once in a working shift; exposure } \\
\text { to these risks is } 120 \text { minutes; possible } \\
\text { minor injuries, sick absenteeism up to } \\
\text { one month }\end{array}$ & 2 & 3 & 2 & 12 & acceptable \\
\hline 10. & $\begin{array}{l}\text { Cuts and } \\
\text { abrasions }\end{array}$ & $\begin{array}{l}\text { Occurs } 2 \text { times in a working shift; } \\
\text { exposure to these risks is } 165 \text { minutes; } \\
\text { considerable injuries, sick absenteeism } \\
\text { up to half a year }\end{array}$ & 2 & 3 & 3 & 18 & acceptable \\
\hline 11. & $\begin{array}{l}\text { Compresse } \\
\text { d air }\end{array}$ & $\begin{array}{l}\text { Occurs once in a working shift; exposure } \\
\text { to these risks is } 120 \text { minutes; } \\
\text { considerable injuries, sick absenteeism } \\
\text { up to half a year }\end{array}$ & 2 & 3 & 3 & 18 & acceptable \\
\hline 12. & Fire & $\begin{array}{l}\text { Occurs once in a working shift; exposure } \\
\text { to these risk is } 120 \text { minutes; possible } \\
\text { death }\end{array}$ & 2 & 3 & 5 & 30 & acceptable \\
\hline 13. & $\begin{array}{l}\text { Other } \\
\text { mechanical } \\
\text { risks }\end{array}$ & $\begin{array}{l}\text { Occurs } 2 \text { times in a working shift; } \\
\text { exposure to these risks is } 165 \text { minutes; } \\
\text { serious bodily injury, sick absenteeism } \\
\text { above half a year }\end{array}$ & 2 & 3 & 4 & 24 & acceptable \\
\hline 14. & $\begin{array}{l}\text { Energy } \\
\text { sources: } \\
\text { steam, } \\
\text { water, } \\
\text { hydraulic } \\
\text { systems }\end{array}$ & $\begin{array}{l}\text { Occurs } 3 \text { times in a working shift; } \\
\text { exposure to these risks is } 225 \text { minutes; } \\
\text { serious bodily injury, sick absenteeism } \\
\text { above half a year }\end{array}$ & 2 & 3 & 4 & 24 & acceptable \\
\hline 15. & $\begin{array}{l}\text { Production } \\
\text { loss }\end{array}$ & $\begin{array}{l}\text { Occurs once in a working shift; exposure } \\
\text { to these risks is } 80 \text { minutes; minor } \\
\text { injuries, sick absenteeism up to } 1 \text { week }\end{array}$ & 2 & 2 & 1 & 2 & acceptable \\
\hline 16. & $\begin{array}{l}\text { Disinformati } \\
\text { on }\end{array}$ & $\begin{array}{l}\text { Occurs } 3 \text { times in a working shift; } \\
\text { exposure to these risks is } 95 \text { minutes; } \\
\text { minor injuries, sick absenteeism up to } 1 \\
\text { week }\end{array}$ & 2 & 2 & 1 & 2 & acceptable \\
\hline 17. & Strain & $\begin{array}{l}\text { Occurs } 3 \text { times in a working shift; } \\
\text { exposure to these risks is } 185 \text { minutes; } \\
\text { possible minor injuries, sick } \\
\text { absenteeism up to one month }\end{array}$ & 2 & 3 & 2 & 12 & acceptable \\
\hline
\end{tabular}

Risk assessment can be made on three levels, namely (Romanowska-Słomka, 2015): unacceptable risk- immediately discontinue the work, improve the working conditions, $125>R>99$; partly acceptable risk- eliminate the causes and mitigate the risk effects, implement new control mechanisms, assess the effectiveness of the currently used control mechanisms, 99>R $>51$; acceptable risk- control and carry out the currently used preventive actions, $51>\mathrm{R}>1$.

Based on the Time Study and the Checklist, 17 main risks occurring at the Glass Production Line Operator's Workstation have been identified. The risk analysis and assessment has found that all of them are at an acceptable level. The greatest risk 
concerns fire hazards (30), mechanical hazards (24) and energy source hazards (24). These are associated with activities, such as replacing tin coolers, tightening the Tank Furnace, cleaning glass coolers, melting tin, cleaning, temperature inspection of the Tank Furnace bottom, Tin Tank and Glass Annealing Furnace inspection, control of the flow of process-aiding gases (nitrogen, hydrogen, sulphur, oxygen). Only three risks, namely production loss, disinformation and strain, were characterized by a lower exposure level; the remaining risks showed an occasional exposure. The greatest effects were associated with a fire, contact with suffocating gases, mechanical hazards and energy sources. The probability of all identified risk was low. Moreover, when looking at the Glass Production Line Operator's Workstation, it is also worth considering risk assessment for risks associated with irregular activities; in that case, however, the Time Study will change.

\section{CONCLUSION}

To sum up the discussion in the present article the following conclusions can be drawn. First a worker employed in the enterprise under discussion may perform different tasks and work at several workstations; therefore, in order to make the picture of his/her work process more credible, it is worth of using risk assessment for specific tasks and activities performed by them. Working days may differ from one another due to various operating changes, the prevailing microclimate, and the scope of additional or irregular tasks; hence, the parameter of probability and exposure to risks will not be identical, so it is advisable, therefore, to adopt risk analysis and assessment criteria that will correspond to the working conditions and, on this basis, to conduct occupational risk assessment activities. Risk assessment should take into account all work aspects, such as the task duration, difficulty level, working position (ergonomic and nonergonomic), the number of tasks most often repeating themselves, break time, work dynamic, work type, workstation multiplicity, branch specificity, the number of workstations per worker, irregular activities, the worker's health condition, etc. Occupational risk for the same workstation will be different, when performed activities differ (in duration, shift, the number of auxiliary staff, etc.); Available and recommended risk analysis and assessment methods can be helpful, but, at the same time, may be too general for more complex workstations and not represent the actual risk level. Risk assessment for a task enables the selection of risk assessment criteria, whereby it is more reliable and adjusted to given workstations.

\section{REFERENCES}

Kaczmarek, T., 2010. Zarządzanie ryzykiem [Risk management]. WNT, Warsaw.

Marcatto, F., Colautti, L., Larese Filon, F., Luis O., Di Blas, L., Cavallero, C. Ferrante, D., 2016. Work-related stress risk factors and health outcomes in public sector employees. Safety Science, 89, November, 274-278.

Martyniak, Z., 1996. Metody organizowania procesów pracy [Methods of organizing work processes]. PWE, Warsaw.

PN-ISO 31000:2018. PKN, Warsaw.

PN-ISO 45001:2018. PKN, Warsaw.

Romanowska-Słomka, I., Słomka, A., 2015. Ocena ryzyka zawodowego [Assessment of occupational ris]. Tarbonus Sp z 0.0., Krakow-Tarnobrzeg. 
Szklarzyk, P., Klimecka-Tatar, D., Kleszcz, D., 2016. Obowiązki prawne i systemowe w ocenie ryzyka zawodowego, jako element zapewnienia odpowiedniego poziomu bezpieczeństwa $i$ higieny pracy [Legal and system obligations in the assessment of occupational risk, as an element of the assurance of the appropriate Health \& Safety level]. Journal Zeszyty Naukowe. Quality. Production. Improvement no. 1, $132-145$.

Wojtyto, D., 2018. Risk Assessment for the Production Process. International Scientific Journal Science, Business, Society, 3.

Wojtyto, D., Rydz, D., 2018. Ocena ryzyka dla zadania w kontekście procesu pracy kierowcy autobusu [Risk assessment for a task in the context of the bus driver's work process]. Journal Autobusy. Technika, Eksploatacja, Systemy Transportowe, 6, 1284-1288.

Yao, Y., Peng, Y., Li, X., Zhang, A., 2018. Research on safety risk management of civil construction projects based on risk matrix method. IOP Conf. Series: Materials Science and Engineering 392, 062080, doi:10.1088/1757-899X/392/6/062080. 